Digital Press Social Sciences and Humanities

RETRACTION NOTE: On the Pursue of World Heritage Status: Conservation vs Tourism

Dwirahmi Suryandari

Proceeding of Indonesia Heritage Tourism Forum 2019 (IHTF 2019)

Dewi Pratika Ayu Dhira Pradati (eds) 


\title{
Retraction Note: On the Pursue of World Heritage Status: Conservation vs Tourism
}

\author{
Dwirahmi Suryandari* \\ Badan Pengelola Kawasan Kota lama Semarang, Semarang, Indonesia \\ *email: anastasia.dwirahmi@gmail.com
}

As of 22 January 2021, the following article has been retracted from the UGM Digital Press Social Sciences and Humanities:

"On the Pursue of World Heritage Status: Conservation vs Tourism" by Dwirahmi Suryandari, Digital Press Social Sciences and Humanities, 4, 00005.

https://doi.org/10.29037/digitalpress.44352

The original article is registered through this URL

https://digitalpress.ugm.ac.id/article/352

as decided by authors and conference organizers on the basis of publication redundancy. It may also encourage potential publication plagiarism.

The retracted article will remain in public domain, that is maintaining its appearance on UGM Digital Press web archive and Proceeding of Indonesia Heritage Tourism Forum 2019 (IHTF 2019) printed version. However, it will receive a watermark to accentuate its retracted status. 